\title{
Calcium Ions, Oxygen and Acetylene Reduction (Nitrogen Fixation) in the Unicellular Cyanobacterium Gloeocapsa sp. 1430/3
}

\author{
By A. FALAH HAMADI AND JOHN R. GALLON* \\ Department of Biochemistry, University College of Swansea, Singleton Park, \\ Swansea SA2 8PP, U.K.
}

(Received 25 July 1980; revised 19 November 1980)

\begin{abstract}
Cultures of Gloeocapsa sp. 1430/3 rapidly and irreversibly lost their ability to reduce acetylene when incubated with $1 \mathrm{mM}$-EDTA, either in the light or aerobically in the dark. However, EDTA did not inhibit acetylene reduction by cultures of Gloeocapsa incubated anaerobically in the dark. It is suggested that EDTA depletes the cyanobacterial cells of $\mathrm{Ca}^{2+}$ and thereby destroys a $\mathrm{Ca}^{2+}$-dependent process by which nitrogenase is protected from inactivation by oxygen.
\end{abstract}

\section{INTRODUCTION}

Acetylene reduction ( $\mathrm{N}_{2}$ fixation) by cultures of several species of cyanobacteria is inhibited by the addition of chelating agents such as EDTA (Gallon, 1978). In most strains simultaneous addition of $\mathrm{MgCl}_{2}, \mathrm{CaCl}_{2}, \mathrm{SrCl}_{2}$ or $\mathrm{BaCl}_{2}$ counteracts the effect of EDTA, but in cultures of the unicellular cyanobacterium Gloeocapsa sp. (Gloeothece sp.), only $\mathrm{CaCl}_{2}$ prevents the inhibition: $\mathrm{MgCl}_{2}, \mathrm{SrCl}_{2}$ and $\mathrm{BaCl}_{2}$ themselves inhibit acetylene reduction (Gallon, 1978). Because EDTA is a polar molecule which does not readily enter cells (Albert, 1973), it probably exerts its effect on acetylene reduction indirectly. Addition of EDTA to a culture would decrease the concentration of free divalent cations in the medium and could thereby cause their efflux from the cyanobacterial cells. The consequent lowering of the intracellular concentrations of these ions might then inhibit acetylene reduction. Acetylene reduction in Gloeocapsa appears specifically to require $\mathrm{Ca}^{2+}$ (Gallon, 1978).

This paper describes investigations into the nature of the $\mathrm{Ca}^{2+}$ requirement for acetylene reduction in Gloeocapsa sp. 1430/3.

\section{METHODS}

Growth of cultures. Gloeocapsa sp. 1430/3 (Culture Centre of Algae and Protozoa, Cambridge) was grown in 151 of sterile medium free of combined nitrogen (Gallon et al., 1978).

Preparation of extracts. For assay of nitrogenase and reductant-dependent ATPase, extracts of Gloeocapsa were prepared at room temperature $\left(20^{\circ} \mathrm{C}\right)$ by a modification of the method of Gallon et al. (1972). Between 5 and $7 \mathrm{~d}$ after inoculation, $5 \mathrm{l}$ of culture was removed and allowed to settle under gravity for $2 \mathrm{~h}$. As much as possible of the culture medium was carefully removed and the cells were resuspended in an equal volume of $20 \mathrm{mM}-\mathrm{N}$-2-hydroxyethylpiperazine- $N^{\prime}$-2-ethanesulphonic acid (HEPES)/ $\mathrm{NaOH}$ buffer $\mathrm{pH} 7 \cdot 5$, transferred to a measuring cylinder and allowed to settle once more. The supernatant was discarded, and the settled cells (usually less than $10 \mathrm{ml}$ ) were transferred to a darkened test tube and bubbled with $\mathrm{N}_{2}$ for $15 \mathrm{~min}$. Sodium dithionite was added to a final concentration of $1 \mathrm{mM}$, and the cells were broken in a French press at $138 \mathrm{MPa}$ and collected, under $\mathrm{N}_{2}$, in a darkened vessel. A cell-free extract was obtained by centrifugation at $10000 \mathrm{~g}$ for $20 \mathrm{~min}$ in a sealed tube flushed with $\mathrm{N}_{2}$. Nitrogenase activity could then be detected in the supernatant, in contrast to the preparations of Gallon et al. (1972). Alternatively, settled cells, prepared as above, were bubbled with $\mathrm{N}_{2}$ for 
15 min and then broken under $N_{2}$ by four passages through a Yeda press at 17.2 MPa. Nitrogenase prepared in this way could be sedimented by anaerobic centrifugation at $10000 \mathrm{~g}$ for $20 \mathrm{~min}$.

For the assay of $\mathrm{Ca}^{2+}$-dependent ATPase, extracts of Gloeocapsa were prepared at $4{ }^{\circ} \mathrm{C}$ as described by Tözüm \& Gallon (1979).

Enzyme assays. $\mathrm{N}_{2}$ fixation by intact cells was measured by the acetylene reduction technique of Tözüm et al. (1977), or using cultures concentrated 20- to 50 -fold and $5 \mathrm{~min}$ incubation with acetylene (Tözüm \& Gallon, 1979). HEPES/NaOH buffer pH $7.5(5 \mathrm{mM})$ was added to all incubations. Anaerobic conditions were produced by flushing cultures with $\mathrm{N}_{2}$ or Ar for 2 to $5 \mathrm{~min}$ prior to sealing the incubation vessels. To demonstrate that anaerobic conditions persisted throughout the incubation, a $1.5 \mathrm{ml}$ centrifuge tube containing $1 \mathrm{ml}$ methylene blue $\left(50 \mathrm{mg} \mathrm{l}^{-1}\right.$ in $\left.2 \mathrm{mM}-\mathrm{NaOH}\right)$ decolorized by heating with D-glucose $\left(20 \mathrm{~g} \mathrm{l}^{-1}\right)$ (Meynell \& Meynell, 1970) was included in these vessels. Occasionally, a tube containing $1 \mathrm{ml}$ pyrogallol $\left(50 \mathrm{~g} \mathrm{I}^{-1}\right.$ in $\left.10 \mathrm{M}-\mathrm{KOH}\right)$ was also included, to absorb any residual traces of oxygen. However, the effects of anaerobiosis on acetylene reduction were identical in the presence or absence of alkaline pyrogallol.

Nitrogenase activity in extracts was measured at $25^{\circ} \mathrm{C}$ as described by Gallon et al. (1972), except that the reactants were enclosed in $25 \mathrm{ml}$ sealed serum bottles and the reaction was started by injection, through the seal, of $0.5 \mathrm{ml}$ of extract. Control incubations, containing either boiled extract or unbroken cells, were included in all assays. Unbroken cells were usually, but not always, inactive under the conditions of assay; all results were corrected, where necessary, for the activity of any unbroken cells in the enzyme preparation.

Reductant-dependent ATPase was assayed under the same conditions as nitrogenase except that the reaction mixture contained (in a total volume of $2 \mathrm{ml}$ ) Tris/ $\mathrm{HCl}$ buffer $\mathrm{pH} 7.4(50 \mu \mathrm{mol}), \mathrm{MgCl}_{2}(10 \mu \mathrm{mol})$, Tris-ATP $(10 \mu \mathrm{mol})$ and sodium dithionite $(10 \mu \mathrm{mol}) . \mathrm{Ca}^{2+}$-dependent ATPase activity was measured at $25^{\circ} \mathrm{C}$ as described by Rorive \& Kleinzeller (1974), with $0.5 \mathrm{ml}$ of extract. In both ATPase assays inorganic phosphate produced by hydrolysis of ATP was measured by the method of LeBel et al. (1978). Boiled enzyme controls and controls lacking sodium dithionite or $\mathrm{Ca}^{2+}$ were included in all assays.

Other measurements. Photosynthetic $\mathrm{O}_{2}$ evolution was measured polarographically at $25^{\circ} \mathrm{C}$ under illumination at $2500 \mathrm{~lx}$, in a Clark-type oxygen electrode (Rank Bros, Bottisham, Cambs). Intracellular ATP was measured as described by Mullineaux et al. (1980) after incubation of cultures with or without 1 mM-EDTA. Protein was measured by the method of Bailey (1962). Cell counts were performed in a Hawksley haemocytometer.

Special chemicals. $N^{\prime}$-(3,4-Dichlorophenyl)- $N, N$-dimethylurea (DCMU) was obtained from DuPont (U.K.), London. 6-Chloro- $N$-ethyl- $N^{\prime}$-(1-methylethyl)-1,3,5-triazine-2,4-diamine (atrazine) was kindly supplied by CibaGeigy. Ionophore A23187 was a generous gift from Dr R. L. Hamill, Lilly Research Laboratories, Indianapolis, U.S.A.

\section{RESULTS AND DISCUSSION}

\section{EDTA and acetylene reduction}

On addition of $1 \mathrm{mM}$-EDTA to illuminated, aerobically grown cultures, nitrogenase activity disappeared with a half-life of about $2.5 \mathrm{~min}$ and had fallen almost to zero within $20 \mathrm{~min}$ (Fig. 1). Following $20 \mathrm{~min}$ exposure to EDTA, no nitrogenase activity was detected within $4 \mathrm{~h}$ of resuspension in fresh medium. On the other hand, addition of $5 \mathrm{mM}-\mathrm{CaCl}_{2}$ within 15 min of adding EDTA almost completely prevented any inhibition of acetylene reduction during the following $60 \mathrm{~min}$ (Fig. 2). Thus, EDTA appeared to cause a rapid, reversible, loss of nitrogenase activity, followed by irreversible inactivation of the enzyme after more than 15 min exposure.

When 20 min or more elapsed between the addition of EDTA and that of $\mathrm{CaCl}_{2}$, little or no nitrogenase activity could be detected in aerobic, illuminated cultures during the following 30 to $60 \mathrm{~min}$. Subsequently, however, the ability to reduce acetylene gradually reappeared (Fig. 3). After an initial lag period (normally about $30 \mathrm{~min}$ ) following the addition of $\mathrm{CaCl}_{2}$, this reappearance of nitrogenase activity was linear, and by $7 \mathrm{~h}$ the activity was about $80 \%$ of that in a control culture to which no EDTA had been added (Fig. 3). Thereafter, nitrogenase activity continued to increase, though at a reduced rate; by $12 \mathrm{~h}$ the activity of experimental cultures frequently exceeded that of the controls. No reappearance of nitrogenase activity was observed when $\mathrm{MgCl}_{2}$ was added instead of $\mathrm{CaCl}_{2}$.

The reappearance of nitrogenase activity was completely abolished by addition of chloramphenicol $\left(0 \cdot 1 \cdot \mathrm{mg} \mathrm{ml}^{-1}\right)$ or $2 \mathrm{mM}-\mathrm{NH}_{4} \mathrm{Cl}$. Chloramphenicol at this concentration markedly inhibits incorporation, by Gloeocapsa, of radioactivity from $\mathrm{Na}_{2}{ }^{14} \mathrm{CO}_{3}$ into protein (A. F. 


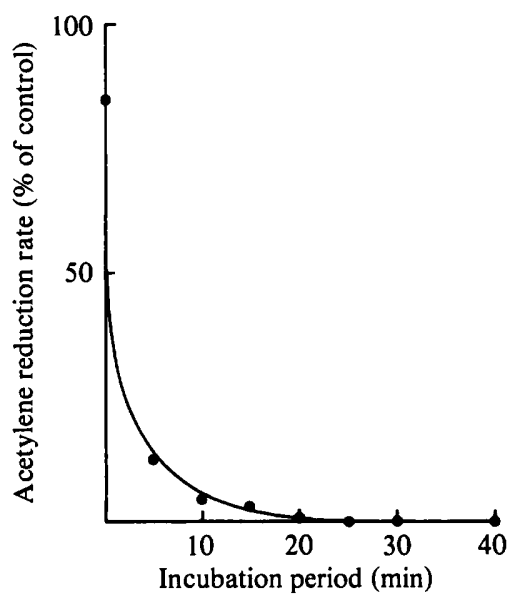

Fig. 1

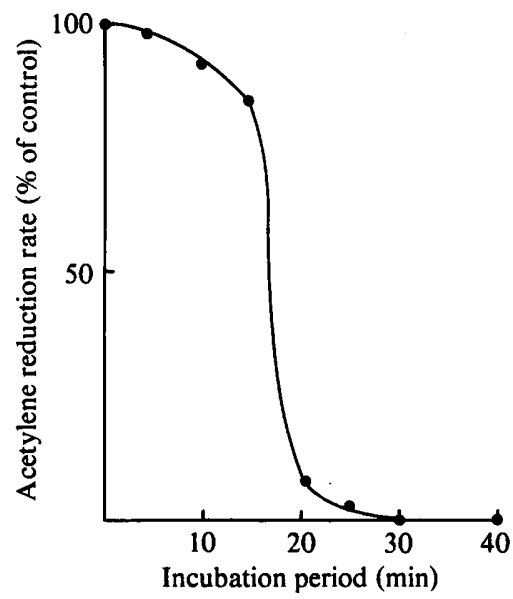

Fig. 2

Fig. 1. Effect of $1 \mathrm{mM}$-EDTA (added at zero time) on acetylene reduction by cultures of Gloeocapsa sp. 1430/3. After incubation for the period indicated, the rate of acetylene reduction was measured over the following $5 \mathrm{~min}$. Activity is expressed relative to the activity of a control to which no EDTA was added. Each point represents the mean of at least five determinations.

Fig. 2. Effect of $\mathrm{CaCl}_{2}$ on acetylene reduction by cultures of Gloeocapsa sp. 1430/3 incubated with EDTA. $\mathrm{CaCl}_{2}(5 \mathrm{mM})$ was added to cultures preincubated for the period indicated in the presence of 1 mM-EDTA (added at zero time). The rate of acetylene reduction was then measured over the following $60 \mathrm{~min}$. Activity is expressed relative to a control lacking EDTA. Each point represents the mean of at least five determinations.

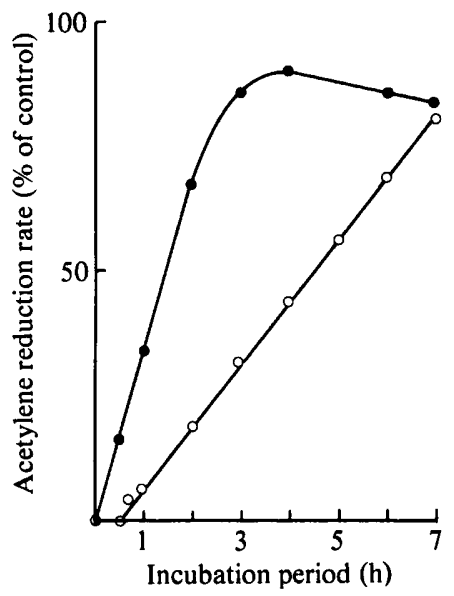

Fig. 3. Reappearance of nitrogenase activity in cultures of Gloeocapsa sp. 1430/3 treated with 1 mMEDTA, followed $20 \mathrm{~min}$ later by $5 \mathrm{mM}-\mathrm{CaCl}_{2}$. After further incubation for the period indicated, either in the light $(O)$ or in the dark $(O)$, the rate of acetylene reduction was measured over the following $60 \mathrm{~min}$. Activity is expressed relative to the activity of similar cultures to which no EDTA had been added. Each point represents the mean of at least six determinations.

Hamadi, unpublished observation), whilst $\mathrm{NH}_{4}{ }^{+}$represses nitrogenase biosynthesis, directly or indirectly, in $\mathrm{N}_{2}$-fixing organisms, including cyanobacteria (Stewart, 1977). Thus, addition of EDTA to illuminated, aerobic cultures leads, after $20 \mathrm{~min}$, to an irreversible inactivation of existing nitrogenase, and the ability to reduce acetylene reappears following addition of $\mathrm{CaCl}_{2}$, probably as a result of the synthesis of new enzyme. 
The ability to reduce acetylene also reappeared when aerobic, illuminated cultures treated with EDTA and then, $20 \mathrm{~min}$ later, with $\mathrm{CaCl}_{2}$ were incubated in the dark. However, in contrast to the response of cultures incubated in the light, there was no lag period and, although the activity of nitrogenase was lower in the dark than in the light, the initial rate of reappearance of this activity was greater in the dark (Fig. 3). One possible explanation for this is that, in the dark, there is no photosynthetic $\mathrm{O}_{2}$ evolution to inactivate newly synthesized nitrogenase (see Tözüm \& Gallon, 1979) or, perhaps, to inhibit nitrogenase synthesis, as occurs in other $\mathrm{N}_{2}$-fixing organisms (Eady et al., 1978; Robson, 1979a). In the dark, acetylene reduction reached a peak after about $4 \mathrm{~h}$ and then slowly declined (Fig. 3), suggesting that Gloeocapsa synthesizes nitrogenase in the dark for only limited periods.

Exposure to $1 \mathrm{mM}$-EDTA for $60 \mathrm{~min}$ completely inhibited acetylene reduction by illuminated cultures incubated under an atmosphere of $\mathrm{N}_{2}, \mathrm{Ar}$, air or $\mathrm{Ar} / \mathrm{O}_{2}(4: 1, \mathrm{v} / \mathrm{v})$. In the dark, however, EDTA stimulated, rather than inhibited, acetylene reduction after incubation for 60 min under either $\mathrm{N}_{2}$ or $\mathrm{Ar}$, though under air or $\mathrm{Ar} / \mathrm{O}_{2}$ the chelating agent was as inhibitory as in the light (Hamadi \& Gallon, 1979). Similarly, $5 \mathrm{mM}-\mathrm{MgCl}_{2}$, which inhibited acetylene reduction by illuminated, aerobic cultures (Gallon, 1978), did not inhibit acetylene reduction by cultures incubated for $60 \mathrm{~min}$ anaerobically in the dark (Hamadi \& Gallon, 1979). The $\mathrm{Ca}^{2+}$ requirement for $\mathrm{N}_{2}$ fixation by Gloeocapsa is apparently evident only in the presence of $\mathrm{O}_{2}$. In the light, anaerobic conditions cannot be established because of photosynthetic $\mathrm{O}_{2}$ evolution.

During longer dark, anaerobic incubation with $1 \mathrm{mM}$-EDTA, the ability to reduce acetylene was lost with a half-life of about $2 \mathrm{~h}$. In contrast to the response of aerobic, illuminated cultures, either $5 \mathrm{mM}-\mathrm{CaCl}_{2}$ or $5 \mathrm{mM}-\mathrm{MgCl}_{2}$, added simultaneously with EDTA, markedly decreased the rate of this disappearance (Fig. 4). EDTA appears to inhibit several metabolic processes in Gloeocapsa (Hamadi \& Gallon, 1979) but its rapid effect on acetylene reduction in the presence of $\mathrm{O}_{2}$ is unique in that it is prevented only by $\mathrm{Ca}^{2+}$ and not by $\mathrm{Mg}^{2+}$.

When cultures were incubated in the presence of $1 \mathrm{mM}$-EDTA for $60 \mathrm{~min}$ in the dark, complete inhibition of acetylene reduction was obtained only when the partial pressure of $\mathrm{O}_{2}$ was $0.02 \mathrm{~atm}$ or more (Fig. 5), while complete inhibition in illuminated cultures was achieved in the absence of added $\mathrm{O}_{2}$. It appeared, therefore, that photosynthesis generated a higher intracellular concentration of $\mathrm{O}_{2}$ in illuminated cells than existed in cultures incubated in the dark with an $\mathrm{O}_{2}$ partial pressure below 0.02 atm. However, even in the presence of $10 \mu \mathrm{M}$ DCMU or $10 \mu \mathrm{M}$-atrazine, which completely abolished photosynthetic $\mathrm{O}_{2}$ evolution, $1 \mathrm{mM}$ EDTA caused an $80 \%$ inhibition of acetylene reduction by illuminated cultures incubated under $\operatorname{Ar}$ or $\mathrm{N}_{2}$.

Three possible explanations for the different effect of EDTA under anaerobic conditions in the light and dark were examined. Firstly, EDTA may inhibit acetylene reduction only when the synthesis of ATP is coupled to electron transport. Secondly, addition of EDTA to cultures of Gloeocapsa might disrupt a $\mathrm{Ca}^{2+}$-dependent mechanism which normally protects nitrogenase from inhibition by $\mathrm{O}_{2}$. Although no $\mathrm{O}_{2}$ evolution could be measured in illuminated cultures of Gloeocapsa exposed to DCMU or atrazine, there may still be sufficient production of $\mathrm{O}_{2}$ in the presence of these inhibitors to allow EDTA partially to inhibit nitrogenase in illuminated cultures incubated anaerobically. Thirdly, it is possible that EDTA fails to inhibit acetylene reduction by cultures incubated anaerobically in the dark because under these conditions there is little or no efflux of $\mathrm{Ca}^{2+}$ from the cyanobacterial cells.

\section{EDTA and ATP synthesis}

Addition of $1 \mathrm{mM}$-EDTA to illuminated cultures caused an immediate fall in the intracellular concentration of ATP from 2.20 to 1.75 pmol $\left(10^{6} \text { cells }\right)^{-1}$. However, within $1 \mathrm{~min}$, this concentration had returned to that found in control cultures. Similarly, when $1 \mathrm{mM}$ - 


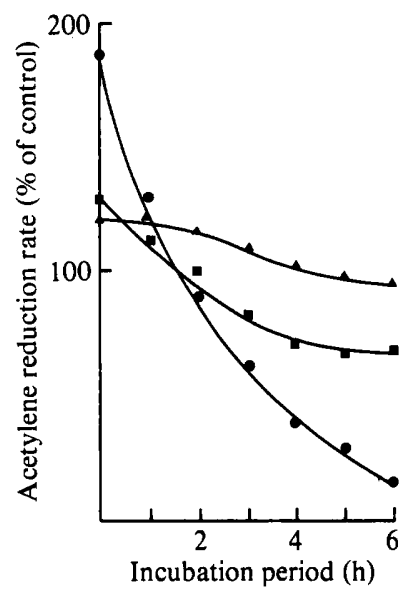

Fig. 4

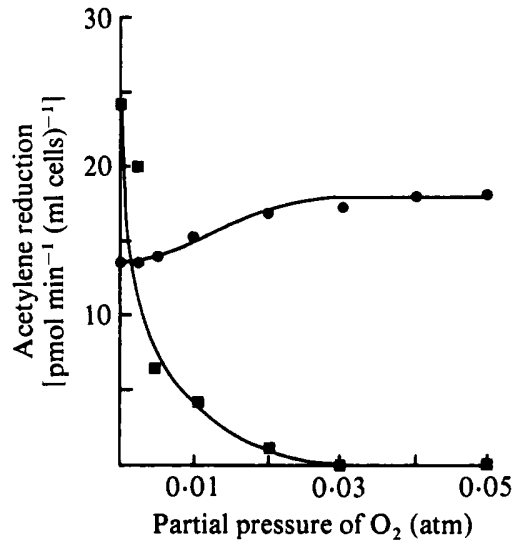

Fig. 5

Fig. 4. Effect of 1 mM-EDTA (added at zero time) on acetylene reduction by cultures of Gloeocapsa sp. 1430/3 incubated anaerobically in the dark (O). Other additions, made simultaneously with EDTA, were $5 \mathrm{mM}^{-\mathrm{CaCl}_{2}}$ ( $\square$ ) or $5 \mathrm{mM}-\mathrm{MgCl}_{2}(\Delta)$. After incubation for the period indicated, the rate of acetylene reduction was measured over the following $60 \mathrm{~min}$. Activity is expressed relative to the activity of similar cultures to which no additions had been made. Each point represents the mean of at least three determinations.

Fig. 5. Effect of $\mathrm{O}_{2}$ on acetylene reduction by cultures of Gloeocapsa sp. 1430/3 incubated for $60 \mathrm{~min}$ in the dark with ( $\square$ ) or without (O) 1 mM-EDTA. The data shown are from a single experiment but are typical.

EDTA was added to cultures incubated aerobically in the dark, only a transient decrease in the intracellular concentration of ATP was observed. EDTA therefore evidently disrupts neither photosynthetic phosphorylation nor oxidative phosphorylation to any great extent.

In the presence of $10 \mu \mathrm{M}$-(3-chlorophenyl)hydrazonopropanedinitrile (CCCP) or $10 \mu \mathrm{M}$ 2,4-dinitrophenol, which are known to uncouple respiratory ATP synthesis (Heytler, 1979), cultures incubated for $60 \mathrm{~min}$ aerobically in the dark reduced acetylene at rates similar to those of cultures incubated anaerobically without additions. EDTA inhibited acetylene reduction in aerobic cultures incubated with CCCP or 2,4-dinitrophenol, but not in anaerobic cultures. Assuming that CCCP and 2,4-dinitrophenol had been effective, ATP for $\mathrm{N}_{2}$ fixation could be supplied only by mechanisms which generate ATP under anaerobic conditions, particularly substrate level phosphorylation. This suggests that the effect of EDTA is not related to the mechanism of ATP synthesis within the cyanobacterial cells.

The addition of $5 \mathrm{mM}-\mathrm{CaCl}_{2}$ stimulated the ATPase activity of extracts of Gloeocapsa. This stimulation was most marked in extracts from cultures pretreated for 20 min with $1 \mathrm{~mm}$-EDTA, in which $\mathrm{Ca}^{2+}$-dependent ATPase activity reached 0.25 to $0.5 \mathrm{nkat}$ (mg protein $)^{-1}$, i.e. 15 to $30 \%$ of the total ATPase activity. Presumably this ATPase would be inhibited in cells treated with EDTA but there is no evidence to link its activity with either electron transport or $\mathrm{N}_{2}$ fixation. Consequently, it remains unlikely that EDTA inhibits acetylene reduction as a result of any effect on ATP synthesis linked to electron transport.

\section{EDTA and $\mathrm{O}_{2}$}

Gloeocapsa nitrogenase is inactivated by $\mathrm{O}_{2}$ in vivo and in vitro (Gallon et al., 1972, 1974). When broken cell preparations of Gloeocapsa prepared with the French press were preincubated for $10 \mathrm{~min}$ in a gas phase containing 0.01 atm $\mathrm{O}_{2}$, nitrogenase activity (assayed anaerobically) was markedly inhibited. The presence of $5 \mathrm{mM}-\mathrm{CaCl}_{2}$ during the pre- 
Table 1. Effects of EDTA, $\mathrm{CaCl}_{2}$ and $\mathrm{O}_{2}$ on Gloeocapsa nitrogenase activity

\begin{tabular}{|c|c|c|}
\hline Preparation & Addition or treatment & $\begin{array}{l}\text { Acetylene reduction } \\
\text { [pkat }(\mathrm{mg} \text { protein })^{-1} \text { ] }\end{array}$ \\
\hline Broken cells (French press) & $\begin{array}{l}\text { None } \\
5 \mathrm{~mm}-\mathrm{CaCl}_{2} \\
1 \mathrm{~mm}-\mathrm{EDTA} \\
0.01 \text { atm } \mathrm{O}_{2} \\
0.01 \text { atm O} \\
2\end{array}$ & $\begin{array}{l}3 \cdot 78 \\
5 \cdot 02 \\
3 \cdot 97 \\
0.64 \\
1.02\end{array}$ \\
\hline Cell-free extract (French press) & $\begin{array}{l}\text { None } \\
5 \mathrm{mM}-\mathrm{CaCl}_{2}\end{array}$ & $\begin{array}{r}10 \cdot 58 \\
7.43\end{array}$ \\
\hline Broken cells (Yeda press) & $\begin{array}{l}\text { None } \\
5 \mathrm{mM}-\mathrm{CaCl}_{2}\end{array}$ & $\begin{array}{l}1.70 \\
1.47\end{array}$ \\
\hline
\end{tabular}

incubation did not prevent this inhibition (Table 1). On the other hand, when added to broken cell preparations that had not been exposed to $\mathrm{O}_{2}, 5 \mathrm{~mm}-\mathrm{CaCl}_{2}$ stimulated nitrogenase activity (Table 1), and also increased reductant-dependent ATP hydrolysis from 0.1 to 0.121 nkat (mg protein) ${ }^{-1}$. The stimulatory effect of $\mathrm{CaCl}_{2}$ on acetylene reduction has not been investigated, but it may be significant that $5 \mathrm{mM}-\mathrm{CaCl}_{2}$ inhibited, rather than stimulated, the nitrogenase activity of cell-free extracts from the French press, and broken cell preparations from the Yeda press (Table 1).

The fact that preincubation in the presence of 0.01 atm $\mathrm{O}_{2}$ inhibited nitrogenase activity in vitro even in the presence of $5 \mathrm{mM}-\mathrm{CaCl}_{2}$ suggests that $\mathrm{Ca}^{2+}$ does not interact directly with Gloeocapsa nitrogenase to form an $\mathrm{O}_{2}$-stable complex. However, such a complex might be formed by interaction between $\mathrm{Ca}^{2+}$, nitrogenase and a second protein, analogous to that found in Azotobacter vinelandii by Haaker \& Veeger (1977). In Azotobacter chroococcum, $\mathrm{Mg}^{2+}$ is involved in the formation of such a complex (Robson, 1979b); it is possible that in Gloeocapsa $\mathrm{Ca}^{2+}$ is required.

In certain organisms. $\mathrm{O}_{2}$ inhibits both nitrogenase synthesis and activity (Eady et al., 1978; Robson, $1979 a$ ) and, in aerobically incubated cultures of Gloeocapsa, inhibition of nitrogenase synthesis (by, for example, chloramphenicol or $\mathrm{NH}_{4}^{+}$) leads to a loss of nitrogenase activity with a half-life of about $3.3 \mathrm{~h}$ (see data of Tözüm et al., 1977). However, in the presence of EDTA, nitrogenase activity in Gloeocapsa cultures decayed with a half-life of about $2.5 \mathrm{~min}$ (Fig. 1), so it is unlikely that EDTA inhibits acetylene reduction simply by inhibiting nitrogenase synthesis or by exacerbating any inhibition of nitrogenase synthesis by $\mathrm{O}_{2}$.

Addition of $10 \mu \mathrm{M}$-methyl viologen to $10 \mathrm{~d}$ batch cultures of Gloeocapsa increased the inhibition of acetylene reduction by $\mathrm{O}_{2}$ (Tözüm \& Gallon, 1979). We found that this effect could be prevented by simultaneous addition of $5 \mathrm{mM}-\mathrm{CaCl}_{2}$, suggesting that $\mathrm{Ca}^{2+}$ might protect nitrogenase from the damaging effects of $\mathrm{H}_{2} \mathrm{O}_{2}$ produced by reaction of $\mathrm{O}_{2}$ with reduced methyl viologen. In support of this hypothesis, $5 \mathrm{mM}-\mathrm{CaCl}_{2}$ also reversed the inhibition of acetylene reduction caused by $0.1 \mathrm{mM}-\mathrm{H}_{2} \mathrm{O}_{2}$. Although $5 \mathrm{~mm}-\mathrm{NaCl}$ or, to a lesser extent, $5 \mathrm{mM}-\mathrm{KCl}$ had a similar effect to $\mathrm{CaCl}_{2}$ on the inhibition of acetylene reduction caused by either methyl viologen or $\mathrm{H}_{2} \mathrm{O}_{2}$, neither $\mathrm{NaCl}$ nor $\mathrm{KCl}$ prevented $1 \mathrm{mM}$-EDTA from inhibiting acetylene reduction. Furthermore, addition of $5 \mathrm{~mm}$-sodium ascorbate or catalase (EC $1.11 .1 .6 ; 2.5 \mu \mathrm{kat} \mathrm{ml}^{-1}$ ), which reverse the effect of methyl viologen (Tözüm \& Gallon, 1979), did not reverse the inhibition of acetylene reduction by EDTA. $\mathrm{H}_{2} \mathrm{O}_{2}$ cannot, therefore, be implicated in the $\mathrm{O}_{2}$-dependent inhibition of acetylene 
Table 2. Effect of $\mathrm{CaCl}_{2}$ on the inhibition by organic solvents and sodium lauryl sulphate of acetylene reduction by Gloeocapsa sp. 1430/3

Cells were collected from batch cultures after $10 \mathrm{~d}$ growth. They were then incubated aerobically in the light for $60 \mathrm{~min}$ with the compounds indicated and the rate of acetylene reduction was measured over the following $60 \mathrm{~min}$. The rates of acetylene reduction are typical; the percentages are the means of at least seven observations.

\begin{tabular}{|c|c|c|}
\hline Addition & $\begin{array}{c}\text { Acetylene reduction } \\
{\left[\mathrm{pmol} \mathrm{min}^{-1}(\mathrm{ml} \text { cells })^{-1}\right]}\end{array}$ & $\begin{array}{c}\text { Percentage } \\
\text { of uninhibited } \\
\text { activity }\end{array}$ \\
\hline None & $27 \cdot 3$ & 100 \\
\hline 13 mm-Butan-1-ol & $18 \cdot 3$ & 67 \\
\hline 13 mm-Butan-1-ol $+5 \mathrm{~mm}-\mathrm{CaCl}_{2}$ & $36 \cdot 6$ & 134 \\
\hline $54 \mathrm{~mm}$-Toluene & $18 \cdot 0$ & 66 \\
\hline $54 \mathrm{~mm}$-Toluene $+5 \mathrm{mM}-\mathrm{CaCl}_{2}$ & $30 \cdot 0$ & 110 \\
\hline $1.7 \mathrm{mM}$-Sodium lauryl sulphate & $2 \cdot 2$ & 8 \\
\hline $\begin{array}{l}1.7 \mathrm{mM} \text {-Sodium lauryl sulphate } \\
+5 \mathrm{mM}-\mathrm{CaCl}_{2}\end{array}$ & $28 \cdot 7$ & 105 \\
\hline
\end{tabular}

reduction which follows the addition of EDTA, and there is no evidence that EDTA inhibits the mechanisms by which $\mathrm{H}_{2} \mathrm{O}_{2}$ is destroyed in this organism.

Addition of $1 \mathrm{mM}$-EDTA to cultures of Gloeocapsa stimulated the incorporation of ${ }^{14} \mathrm{CO}_{2}$ into membrane lipids, particularly monogalactosyldiacylglycerol. The extent of stimulation varied from 35 to $118 \%$ but was always observed. Furthermore, $5 \mathrm{~mm}-\mathrm{CaCl}_{2}$ prevented the inhibition of Gloeocapsa nitrogenase activity that was produced by the organic solvents butan-1-ol and toluene and by the surface active agent sodium lauryl sulphate (Table 2). Although the significance of these observations is not clear, it is possible that certain membranes protect nitrogenase from inactivation by $\mathrm{O}_{2}$, either by acting as a diffusion barrier or by providing conformational protection for the enzyme.

\section{EDTA and intracellular $\mathrm{Ca}^{2+}$}

There is no direct evidence that EDTA causes an efflux of $\mathrm{Ca}^{2+}$ from cells of Gloeocapsa. However, such a mechanism is consistent with the idea that EDTA does not enter living cells (Albert, 1973) and is supported by the observation that $\mathrm{Ca}^{2+}$ caused a greater stimulation of ATPase activity in extracts of cultures pre-treated with EDTA than in controls.

Ionophore A23187, which carries divalent cations across membranes (Reed \& Lardy, 1972), has been used by Gallon (1978) to render sensitive to inhibition by EDTA acetylene reduction by certain, usually resistant, cyanobacteria. However, $1 \mathrm{mM}$-EDTA did not inhibit acetylene reduction by cultures of Gloeocapsa incubated anaerobically in the dark for $60 \mathrm{~min}$ with $8 \mu \mathrm{M}$-A23187. Furthermore, when illuminated cultures of Gloeocapsa were incubated with $1 \mathrm{mM}$-EDTA for $20 \mathrm{~min}$ and then transferred to dark, anaerobic conditions, the ability to reduce acetylene reappeared as new nitrogenase was synthesized. Under dark anaerobic conditions, therefore, factors other than a barrier to $\mathrm{Ca}^{2+}$ efflux must protect nitrogenase from inactivation by EDTA because, if EDTA acts as assumed, intracellular $\mathrm{Ca}^{2+}$ would already have been depleted during incubation in the light.

In conclusion, therefore, the most likely explanation for the rapid inhibition of acetylene reduction in Gloeocapsa caused by $1 \mathrm{mM}$-EDTA is that a $\mathrm{Ca}^{2+}$-dependent mechanism, which normally protects nitrogenase from $\mathrm{O}_{2}$, is inactivated.

The authors thank the Royal Society-for financial support. The contributions of Mr N. M. Shaw, Mr G. W. Hughes and Mr S. R. Morris towards this work are also gratefully acknowledged.

\section{RE FERENCES}

Albert, A. (1973). Selective Toxicity, 5th edn. Balley, J. L. (1962). Techniques in Protein Chemistry, London: Chapman \& Hall. p. 293. Amsterdam: Elsevier. 
EAdy, R. R., IsaAck, R., Kennedy, C., Postgate, J. R. \& RATClifFE, H. D. (1978). Nitrogenase synthesis in Klebsiella pneumoniae: comparison of ammonium and oxygen regulation. Journal of General Microbiology 104, 277-285.

GALlON, J. R. (1978). Calcium and nitrogen fixation by Gloeocapsa. In Environmental Role of Nitrogenfixing Blue-green Algae and Asymbiotic Bacteria, edited by U. Granhall. Ecological Bulletins 26, 60-68.

Gallon, J. R., LaRue, T. A. \& KuRz, W. G. W. (1972). Characteristics of nitrogenase activity in broken cell preparations of the blue-green alga Gloeocapsa sp. LB795. Canadian Journal of Microbiology 18, 327-332.

Gallon, J. R., LaRue, T. A. \& Kurz, W. G. W. (1974). Photosynthesis and nitrogenase activity in the blue-green alga Gloeocapsa. Canadian Journal of Microbiology 20, 1633-1637.

Gallon, J. R., Ul-Haque, M. I. \& Chaplin, A. E. (1978). Fluoroacetate metabolism in Gloeocapsa sp. LB795 and its relationship to acetylene reduction (nitrogen fixation). Journal of General Microbiology 106, 329-336.

HAAKER, H. \& VEEgER, C. (1977). Involvement of the cytoplasmic membrane in nitrogen fixation by Azotobacter vinelandii. European Journal of Biochemistry 77, 1-10.

HAmadi, A. F. \& Gallon, J. R. (1979). Studies on the role of calcium ions in acetylene reduction (nitrogen fixation) by Gloeocapsa sp. 1430/3. Biochemical Society Transactions 7, 1266-1267.

HEYTLER, P. G. (1979). Uncouplers of oxidative phosphorylation. Methods in Enzymology 55, 462472.

Lebel, D., Poirier, G. G. \& Beaudoin, A. R.
(1978). A convenient method for the ATPase assay. Analytical Biochemistry 85, 86-89.

Meynell, G. G. \& MEYNELL, E. (1970). Theory and Practice in Experimental Bacteriology, 2nd edn, p. 80. Cambridge: Cambridge University Press.

MullineauX, P. M., Chaplin, A. E. \& Gallon, J. R. (1981). Effects of a light to dark transition on carbon reserves, nitrogen fixation and ATP concentrations in cultures of Gloeocapsa (Gloeothece) sp. 1430/3. Journal of General Microbiology 120, 227-232.

REED, P. W. \& LARDY, H. A. (1972). A23187: a divalent cation ionophore. Journal of Biological Chemistry 247, 6970-6977.

RoBson, R. L. (1979a). $\mathrm{O}_{2}$-repression of nitrogenase synthesis in Azotobacter chroococcum. FEMS Microbiology Letters 5, 259-262.

Robson, R. L. $(1979 b)$. Characterization of an oxygen-stable nitrogenase complex isolated from Azotobacter chroococcum. Biochemical Journal 181, 569-575.

RoRIVE, G. \& KLEINZEller, A. (1974). $\mathrm{Ca}^{2+}$. activated ATPase from renal tubular cells. Methods in Enzymology 32, 303-306.

StewART, W. D. P. (1977). Blue-green algae. In $A$ Treatise on Dinitrogen Fixation, vol. 3, pp. 63-122. Edited by R. W. F. Hardy \& W. S. Silver. New York: Wiley.

Tözừ, S. R. D. \& Gallon, J. R. (1979). The effects of methyl viologen on Gloeocapsa sp. LB795 and their relationship to the inhibition of acetylene reduction (nitrogen fixation) by oxygen. Journal of General Microbiology 111, 313-326.

TözÜm, S. R. D., Ul-HaQue, M. I., Chaplin, A. E. \& GALLON, J. R. (1977). The effect of fluoroacetate on acetylene reduction by Gloeocapsa. Biochemical Society Transactions 5, 1482-1484. 